\title{
SINERGI LEMBAGA TEKNOLOGI FINANSIAL DAN KOPERASI DALAM PEMANFAATAN TEKNOLOGI FINANSIAL OLEH USAHA MIKRO, KECIL, DAN MENENGAH DI NTB ${ }^{1}$
}

\author{
Rr. Retno Rizki Dini Yuliana \\ Pusat Penelitian Ekonomi, Lembaga Ilmu Pengetahuan Indonesia, Jakarta, Indonesia \\ rizkidy@gmail.com
}

\begin{abstract}
Abstrak
Permasalahan keuangan, sumberdaya manusia, dan teknologi merupakan hambatan klasik yang dihadapi Usaha Mikro, Kecil, dan Menengah (UMKM) di Indonesia. Perkembangan teknologi di bidang keuangan yang telah berkembang dalam beberapa tahun terakhir ini dan berdampak pada perubahan perilaku masyarakat dalam bertransaksi keuangan. Hal ini dapat menjadi solusi bagi permasalahan keuangan yang dihadapi UMKM. Keterbatasan kemampuan dan pengetahuan yang dimiliki pelaku UMKM ternyata disadari oleh lembaga Teknologi Finansial (Tekfin), sehingga lembaga Tekfin mencoba untuk bersinergi dengan Koperasi untuk mengatasi hal tersebut. Penelitian ini bertujuan untuk mengetahui sinergi yang dilakukan oleh lembaga Tekfin dengan Koperasi, serta dampaknya bagi pelaku UMKM, Koperasi, dan lembaga Tekfin, khususnya di Nusa Tenggara Barat (NTB). Penelitian ini menggunakan analisis kualitatif dan deskriptif kuantitatif. Hasil menunjukkan bahwa terdapat dua Koperasi di NTB yang bersinergi dengan lembaga Tekfin yaitu Koperasi Mitra Dhuafa (Komida) dengan Tekfin Pembiayaan Mekar, dan Koperasi Tani (Koptan) Wira Singe dengan Tekfin Pembayaran Mandiri e-cash. Tekfin Mekar menyediakan aplikasi sebagai media bertemunya investor dan peminjam, sedangkan Komida memfasilitasi anggotanya untuk memperoleh pinjaman yang didanai oleh Tekfin Mekar, semeentara Tekfin Mandiri e-cash merupakan Tekfin pembayaran yang serupa dengan rekening ponsel, bekerja sama dengan Koptan Wira Singe membantu Bank Mandiri untuk mengedukasi dan memfasilitasi para anggotanya agar dapat mengakses Mandiri e-cash. Dari kerja sama yang dilakukan ini, baik lembaga Tekfin, Koperasi, maupun anggota memperoleh dampak positif berupa imbal hasil, bertambahnya jumlah nasabah, bantuan permodalan, peningkatan transaksi penjualan dan keuntungan, bertambahnya jumlah relasi usaha, serta memperoleh literasi keuangan.
\end{abstract}

Kata kunci : teknologi finansial, koperasi, UMKM.

JEL : $G 23, P 13, L 26$.

\begin{abstract}
The problems of financial, human resources, and technology are the classic problems faced by Micro, Small and Medium Enterprises (MSMEs) in Indonesia. Technological development in the financial sector has developed in recent years and affected to change people's behavior in financial transactions. This can be a solution to the financial problems faced by MSMEs. The limited ability and knowledge possessed by SMEs were recognized by Financial Technology (Fintech) institutions and they tried to synergize with the cooperatives to overcome these problems. This study aims to find out the synergy carried out by Fintech institutions with the cooperatives, and their impact on MSMEs, cooperatives and Fintech institutions, especially in West Nusa Tenggara (NTB). This study used a qualitative analysis and quantitative descriptive. The results show that there are two cooperatives in NTB that synergized with Fintech institutions namely Koperasi Mitra Dhuafa (Komida) with Fintech Mekar, and Koperasi Tani (Koptan) Wira Singe with Fintech Mandiri e-cash. Fintech Mekar provides applications as a medium for meeting investors and borrowers. Komida facilitated its members to obtain a loan funded by Fintech Mekar, while Fintech Mandiri e-cash, a Fintech payment similar to cellphone accounts, cooperating with Koptan Wira Singe helped Bank Mandiri to educate and facilitate its members to be able to access Mandiri e-cash. From this collaboration, both Fintech, cooperative and member institutions have a positive impact in the form of returns, increased number of customers, capital assistance, increased sales and profit transactions, increased number of business relations, and financial literacy.
\end{abstract}

Keywords : financial technology, cooperative, MSMEs.

JEL : G23, P13, L26.

${ }^{1}$ Dipresentasikan dalam Seminar Prosiding The $2^{\text {nd }}$ International Conference on Social Science and Humanities di Jakarta, 25 Oktober 2018 


\section{PENDAHULUAN}

Usaha menengah ke bawah di Indonesia jumlahnya mendominasi yakni mencapai $99,99 \%$ dari total usaha di Indonesia. Jumlah yang besar tersebut memiliki kontribusi yang cukup besar terhadap perekonomian di Indonesia. Bahkan dianggap sebagai penggerak perekonomian Indonesia. Pada tahun 2013, sektor Usaha Mikro, Kecil, dan Menengah (UMKM) mampu menyerap tenaga kerja hampir setengah dari jumlah penduduk Indonesia yaitu sebesar 114 juta orang dan menyumbang PDB sebesar Rp 5.044 Triliun.

Di sisi lain, sektor UMKM ini masih dihadapkan pada permasalahan-permasalahan klasik seperti permasalahan permodalan, sumberdaya manusia, dan teknologi. Kendala dalam mengakses perbankan terjadi karena langkanya sistem pendataan, rendahnya pengetahuan mengenai sistem keuangan, tingginya biaya layanan dan masih buruknya infrastruktur teknologi (Rahman, 2009). Selain itu, rendahnya akses masyarakat berpendapatan rendah dan UMKM terhadap kredit perbankan bukan disebabkan karena tidak layak untuk memperoleh kredit tetapi karena perbankan tidak memiliki data dan informasi terkait dengan kelayakan usaha UMKM (Kshetri, 2016).

Perhatian pemerintah selama ini telah cukup besar pada sektor UMKM. Hal ini antara lain terlihat dengan adanya beberapa program pemerintah yang dimaksudkan untuk membantu UMKM agar mampu berkembang. Beberapa program yang diberikan pemerintah di antaranya program Kredit Usaha Rakyat (KUR), program pemberdayaan dan pelatihan untuk UMKM, pembentukan BUMN Permodalan Nasional Madani yang fokus pada pembiayaan dan pendampingan UMKM, dan program-program lainnya. Namun pada realisasinya, berbagai program tersebut juga mengalami kendala sehingga tidak mampu menjadi solusi bagi para pelaku UMKM. Program KUR misalnya, program ini merupakan program kredit tanpa agunan dengan bunga rendah yang diperuntukkan bagi pelaku usaha UMKM. Namun ternyata perbankan sebagai lembaga penyalur KUR tetap mensyaratkan adanya jaminan untuk pengajuan kredit karena dikhawatirkan KUR ini dianggap sebagai dana bantuan yang tidak wajib untuk dikembalikan. Selain itu, bank penyalur KUR juga sering terkendala dalam menjangkau pelaku UMKM yang berada di luar jangkauan operasionalnya.

Selain melalui perbankan, perhatian Pemerintah juga diberikan melalui koperasi. Koperasi merupakan lembaga keuangan yang umumnya berlokasi lebih dekat dengan masyarakat. Koperasi juga menjadi wadah masyarakat dalam beraktivitas ekonomi di suatu wilayah. Program yang diberikan melalui koperasi diantaranya program 8 juta UMKM go-online pada tahun 2019. Kementerian Koperasi dan UKM melakukan pemberdayaan UMKM dalam hal standarisasi produk, peningkatan SDM, dan akses pembiayaan melalui Pusat Layanan Usaha Terpadu (PLUT) yang tersebar di beberapa provinsi. Salah satu kegiatan yang dilakukan oleh PLUT yaitu pembinaan UMKM dan koperasi dalam memanfaatkan media digital untuk memasarkan produk dan jasanya.

Program Pemerintah melalui koperasi ini sejalan dengan perkembangan teknologi yang terjadi dalam beberapa tahun terakhir ini dan telah turut menggeser perilaku masyarakat dalam bertransaksi keuangan dan jual-beli. Munculnya media e-commerce yang kini telah sangat familiar di masyarakat telah mengubah perilaku transaksi jual-beli masyarakat dari bertransaksi tatap muka langsung hingga kini cukup dengan memanfaatkan telepon seluler dan komputer saja. Saat ini telah mulai marak bermunculan pula aplikasi untuk keuangan atau yang sering disebut dengan Teknologi Finansial (Tekfin). Dengan adanya Tekfin ini, transaksi keuangan menjadi lebih mudah yaitu hanya dengan memanfaatkan telepon seluler dan jaringan internet. Terdapat beberapa jenis Tekfin, namun persentase terbesar yang berkembang di Indonesia yaitu Tekfin Pembiayaan dan Tekfin Pembayaran.

Muchlis (2018) dan Muzdalifa, Rahma, dan Novalia (2018) mengemukakan bahwa terdapat beberapa kendala yang dihadapi Tekfin dalam upaya meningkatkan inklusivitas keuangan di Indonesia yaitu belum meratanya infrastruktur IT di seluruh Indonesia, terbatasnya kemampuan masyarakat di pedesaan dalam mengaplikasikan Tekfin, serta kurangnya literasi mengenai Tekfin yang diberikan oleh Pemerintah. Hal ini 
menunjukkan bahwa pemanfaatan Tekfin oleh UMKM di Indonesia kurang berjalan dengan lancar. Hal tersebut diperkuat dengan hasil penelitian yang dilakukan oleh Morgan dan Trinh (2019) mengenai hubungan antara literasi keuangan dan kesadaran pengembangan Tekfin di Laos, di mana literasi keuangan memiliki korelasi positif dengan tingkat pendidikan, tempat tinggal di perkotaan, pendapatan, serta infrastuktur IT yang belum memadai. Kendala yang dihadapi tersebut berdampak pada rendahnya pemanfaatan Tekfin oleh UMKM. Kendala tersebut diatasi oleh lembaga Tekfin dengan mencoba menggandeng koperasi untuk bekerja sama mengatasi hal tersebut.

Muchlis (2018) dan Rizal, Maulina, dan Kostini (2019) juga telah melakukan penelitian sejenis yaitu mengenai pemanfaatan sistem Tekfin pada Perbankan Syariah dan Koperasi yang dimaksudkan untuk meningkatkan efisiensi maupun kinerja dari kedua lembaga keuangan tersebut. Namun perbedaannya, penelitian ini lebih fokus kepada sistem kerja sama yang dilakukan oleh Tekfin dengan Koperasi. Adapun tujuan dari penelitian ini adalah untuk mengetahui bagaimana sinergi yang dilakukan oleh lembaga Tekfin dengan Koperasi, serta dampaknya bagi pelaku UMKM, koperasi, dan lembaga Tekfin.

\section{TINJAUAN PUSTAKA}

Tekfin dapat dimaknai sebagai gelombang baru perusahaan finansial dengan mengubah cara masyarakat dalam melakukan transaksi pembayaran, mengirim uang, pinjam-meminjam, dan berinvestasi (Chishti \& Barberis, 2016). Perusahaan Tekfin berpotensi mempercepat pencapaian inklusivitas keuangan (Shim \& Shin, 2016). Kemajuan Tekfin melalui penggunaan teknologi internet, layanan jejaring sosial, media sosial, kecerdasan buatan (artificial intelligence), serta analisis big data ini dapat menjangkau masyarakat secara luas, termasuk kelompok masyarakat miskin dan berpendapatan rendah, serta UMK (Lee, 2016; Shim \& Shin, 2016).

Tekfin menawarkan pandangan baru di era industri keuangan digital. Tekfin memfasilitasi perbankan dan non bank untuk melakukan transfer lintas jaringan dan transaksi pembayaran melalui platform (Wonglimpiyarat, 2017). Layanan inovasi pembayaran dapat diklasifikasikan menjadi dua yaitu pembayaran online dan pembayaran seluler. Pembayaran online mencakup transaksi perbankan online, perdagangan elektronik, dan layanan pembayaran. Sedangkan pembayaran seluler mencakup transaksi uang seluler melalui operator jaringan seluler. Dalam perkembangannya hadir model bisnis baru yang memfasilitasi pembayaran lintas batas yaitu melalui platform pertukaran mata uang peer to peer yang mencocokkan mata uang pembeli dan penjual (OECD, 2018).

OECD (2018) juga menjelaskan mengenai model bisnis baru untuk pinjaman dan pendanaan yaitu platform peer to peer. Platform peer to peer terdiri dari beberapa model, di antaranya platform berbasis donasi, platform berbasis pinjaman, dan platform berbasis ekuitas. Penggunaan big data diperlukan dalam platform ini untuk menghitung skor kredit dan menilai risiko pinjaman dengan tujuan untuk meminimalkan risiko kredit yang mungkin terjadi.

Kehadiran Tekfin juga dapat menekan bisnis layanan keuangan informal, seperti rentenir. Menurut KPMG dan Nasscom (2016), Tekfin akan mengubah pola pikir dan strategi bisnis yang semula tradisional konservatif menjadi kolaboratif antara pelaku bisnis riil dengan pelaku Tekfin. Kolaborasi yang dilakukan Tekfin juga memungkinkan perusahaan untuk dapat berkembang lebih cepat dengan biaya yang lebih rendah (Teja, 2018). Kolaborasi perusahaan dengan Tekfin pada umumnya dilakukan melalui investasi modal ventura, program inkubasi bisnis, program laboratorium inovasi, kemitraan strategis, dan program akselerator bagi bisnis Tekfin. Perbankan juga dapat bekerja sama dengan lembaga Tekfin dengan menciptakan lini bisnis baru dalam bidang pembayaran, pemanfaatan keahlian lembaga Tekfin dalam penilaian risiko, pengalaman dalam pelayanan pelanggan, efisiensi operasional, dan pembiayaan yang efisien.

Pada beberapa negara di Asia, lembaga keuangan dan lembaga Tekfin telah melakukan hubungan simbiosis, di mana keduanya akan memperoleh manfaat dari hubungan kerja sama tersebut. Tekfin melihat lembaga keuangan sebagai pintu gerbang di pasar, sedangkan lembaga keuangan dapat beralih ke Tekfin untuk 
tetap berada dalam inovasi keuangan yang berkembang pesat dan mengikuti perubahan peraturan yang ada, serta memperoleh akses data yang besar untuk meningkatkan hubungan dengan pelanggan (Alexander dkk., 2017). Lee dan Shin (2018), mengidentifikasi lima elemen yang terdapat dalam ekosistem Tekfin yaitu lembaga Tekfin, perusahaan pengembang teknologi, pemerintah, konsumen keuangan, dan institusi keuangan tradisional.

Kerja sama yang dilakukan lembaga Tekfin dengan lembaga keuangan di negara lain sebagian besar dilakukan dengan lembaga perbankan. Seperti yang dilakukan Eko Financial Services, Eko mengikuti model perbankan tiga tingkat, yaitu perbankan, koresponden bisnis, dan poin layanan pelanggan. Eko bekerja sama dengan State Bank of India (SBI) dan ICICI Bank. Pada level menengah, Eko berperan menjadi korensponden bisnis. Pada level akhir, Eko bermitra dengan mitra bisnis lokal, seperti pompa bensin dan usaha lainnya yang biasanya sudah bekerja sama dengan perusahaan telekomunikasi dan perusahaan Fast Moving Consumer Goods (FMCG) (Ranganathan \& Kapoor, 2014).

Sedangkan di Kenya, perbankan besar maupun kecil melakukan kerja sama dengan M-Pesa untuk memperluas jaringannya dan menjangkau masyarakat yang sebelumnya belum dilayani oleh lembaga perbankan (Ndung'u, 2018). Beberapa bank di Eropa juga melakukan kemitraan dengan Tekfin di sana. Di antaranya Santander Bank (Inggris) bermitra dengan platform pinjaman peer-to-peer Circle. Goldman Sachs (AS) juga telah menanamkan investasinya ke Tekfin pembayaran dan keuangan alternatif seperti Square, Bluefin Payment, Bill Trust, dan Revolution Money. Selain itu, Citigroup (AS) yang meluncurkan Citi Fintech sebagai layanan perbankan mobile-nya (Romanova \& Kudinska, 2016)growing importance of innovations as well as wide use of technologies have changed the banking business worldwide. Financial technologies (FinTech. Adapun kerangka pemikiran dari penelitian ini yang diadopsi dari beberapa bentuk kolaborasi yang dilakukan lembaga Tekfin dengan lembaga keuangan di beberapa negara lain adalah sebagai berikut.

Kendala yang dihadapi oleh masyarakat ataupun UMKM dalam mengakses dan memanfaatkan Tekfin dapat teratasi dengan kerja sama yang dilakukan oleh Tekfin dengan Koperasi. Koperasi berperan sebagai fasilitator masyarakat maupun UMKM untuk dapat mengakses aplikasi Tekfin.

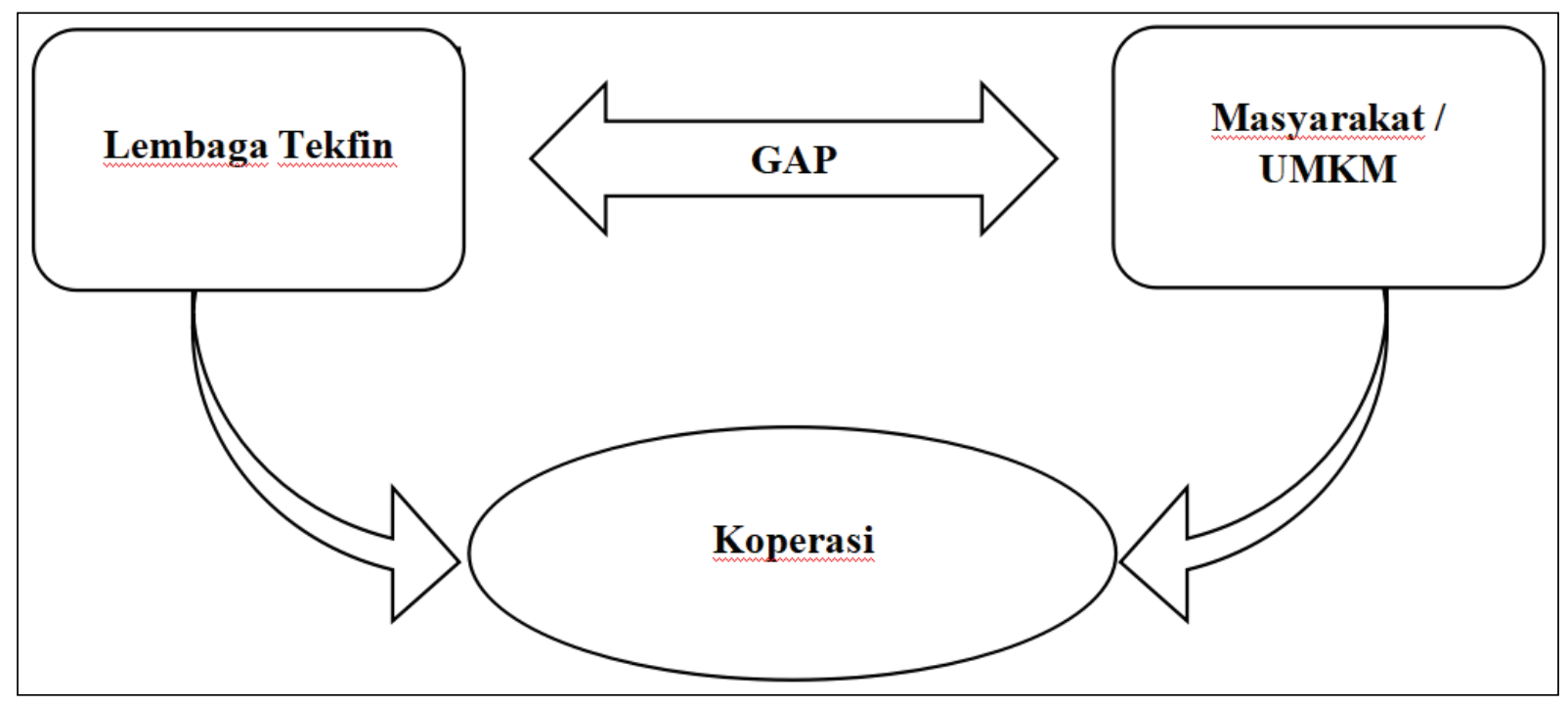

Gambar 1. Kerangka Pemikiran 


\section{METODE PENELITIAN}

Penelitian ini menggunakan metode analisis kualitatif dan deskriptif kuantitatif berdasarkan data primer dan sekunder yang diperoleh dari studi pustaka, wawancara mendalam, dan kuesioner. Wawancara mendalam dilakukan dengan lembaga Tekfin, Koperasi dan UMKM anggota Koperasi. Selanjutnya hasil wawancara mendalam ini dianalisis secara kualitatif untuk mengetahui proses kerja sama yang dilakukan oleh lembaga Tekfin dan Koperasi. Kuesioner dibagikan kepada anggota Koperasi yang menggunakan Tekfin dimana terdapat dua jenis kuesioner yang dibagikan kepada responden, yaitu kuesioner untuk pengguna Tekfin pembiayaan, dan kuesioner untuk Tekfin pembayaran. Masing-masing jenis kuesioner dibagikan kepada 25 orang responden. Responden merupakan nasabah Koperasi yang memanfaatkan Tekfin pembiayaan dan Tekfin pembayaran. Pemilihan responden menggunakan teknik non probability purposive sampling. Hasil kuesioner diolah secara kuantitatif dan kemudian dideskripsikan secara kualitatif, sehingga dapat diketahui dampak yang diperoleh oleh berbagai pihak.

Pemilihan lokasi penelitian di NTB karena provinsi ini merupakan salah satu alternatif destinasi wisata setelah Bali yang sektor pariwisatanya sedang berkembang. Hal tersebut tentunya juga memberikan peluang bagi UMKM untuk ikut berkembang. Selain itu, berdasarkan hasil FGD dan wawancara awal dengan beberapa lembaga Tekfin dan Dinas Koperasi dan UMKM Provinsi NTB pada bulan Februari-Maret 2018 di Jakarta dan NTB diketahui bahwa salah satu provinsi di luar Pulau Jawa yang masyarakatnya telah mengakses Tekfin yaitu NTB, khususnya di Kabupaten Lombok Tengah dan Lombok Barat. Pemanfaatan Tekfin oleh masyarakat di NTB melalui kerja sama yang dilakukan oleh lembaga Tekfin dan koperasi. Terdapat tiga koperasi yang telah bekerja sama dengan lembaga Tekfin yaitu Koperasi Mitra Dhuafa (Komida) di Praya dan Lombok Barat, serta Koperasi Tani Wira Singe. Namun Koperasi yang dijadikan obyek penelitian ini ada dua yaitu Komida Praya dan Koptan Wira Singe karena kedua koperasi tersebut berlokasi di wilayah penyangga pariwisata NTB.

\section{HASIL DAN PEMBAHASAN}

Nusa Tenggara Barat merupakan salah satu provinsi di Indonesia bagian tengah yang saat ini sedang berkembang karena didukung oleh sektor pariwisata. Wilayahnya yang berdekatan dengan Pulau Bali menjadikan NTB sebagai salah satu alternatif destinasi wisata setelah Bali. Perkembangan sektor pariwisata di NTB ini tentunya berdampak pula pada perkembangan UMKM di wilayah tersebut. Jumlah usaha di NTB pada tahun 2017 mencapai 648.827 unit dengan proporsi terbesar merupakan usaha mikro. Jumlah tenaga kerja yang mampu terserap di sektor UMKM yaitu sebanyak 1.415 .641 orang (Hasil FGD dengan Dinas Koperasi dan UMKM Provinsi NTB di NTB, 26 Maret 2018).

Berdasarkan data BPS Provinsi NTB pada tahun 2015, jumlah koperasi di NTB berjumlah 4.049 koperasi. Jumlah koperasi terbanyak berada di Kota Mataram dan Lombok Tengah, yaitu sebanyak 598 koperasi di Kota Mataram dan 563 koperasi di Lombok Tengah. Walaupun jumlah koperasi di NTB cukup banyak, namun ternyata setengah dari jumlah tersebut sudah berstatus tidak aktif, padahal koperasi memiliki peranan yang penting bagi UMKM dan masyarakat berpenghasilan rendah. Keberadaan koperasi yang umumnya lebih dekat dengan masyarakat dan pelaku UMKM seharusnya dapat menjadi alternatif lembaga keuangan maupun sebagai fasilitator penghubung ke lembaga keuangan. Kondisi literasi keuangan masyarakat NTB pun masih sangat rendah yaitu berada pada peringkat ke 33 dari 34 provinsi di Indonesia (wawancara dengan OJK NTB, 2018).

Meskipun demikian, terdapat beberapa koperasi di NTB yang telah melakukan kerja sama dengan lembaga Tekfin, baik sebagai lembaga penyalur dana bagi anggota koperasi maupun untuk mempermudah anggota koperasi dalam bertransaksi keuangan. Koperasi tersebut yaitu Komida di Praya dan Lombok Barat, serta Koperasi Tani (Koptan) Wira Singe. Adapun dua koperasi yang menjadi obyek penelitian ini ada dua yaitu Komida Praya dan Koptan Wira Singe karena keduanya berlokasi di wilayah penyangga pariwisata NTB. 


\section{Sinergi Tekfin Pembiayaan Mekar dan Komida}

Komida merupakan sebuah koperasi yang awalnya berbadan hukum yayasan. Komida didirikan sejak tahun 2005 dan beroperasi di Aceh untuk menangani korban pasca bencana tsunami. Adanya peraturan yang melarang sebuah yayasan untuk mengelola keuangan menyebabkan badan hukum Komida diubah menjadi Koperasi pada tahun 2008. Seiring berjalannya waktu hingga tahun 2018, Komida telah memiliki 203 cabang yang tersebar di 11 provinsi di Indonesia dengan jumlah anggota koperasi mencapai 697.000 orang.

Pola yang digunakan oleh Komida dalam melakukan pembinaan dan pembiayaan kepada para anggotanya adalah dengan menggunakan pola Grameen Bank, di mana pembinaan dan pembiayaan yang diberikan dilakukan berkelompok dan pembayaran pembiayaan dilakukan secara tanggung renteng. Selain itu, seluruh anggota Komida adalah ibu-ibu yang berkelompok sebanyak 5 orang dalam setiap kelompoknya. Sesuai dengan nama dan visinya, Komida hanya melayani dan beranggotakan perempuan yang memiliki penghasilan rendah.

Komida memiliki beberapa jenis produk yaitu pinjaman pendidikan, pinjaman sanitasi, pinjaman harta, pinjaman umum, dan pinjaman mikro bisnis. Pinjaman yang diberikan oleh pihak Komida berupa pinjaman tunai dan non tunai. Jenis produk pinjaman pendidikan, sanitasi, dan harta umumnya diberikan dalam bentuk non tunai. Pinjaman pendidikan diberikan dengan cara dibayarkan langsung kepada pihak sekolah oleh Komida. Pinjaman sanitasi akan diberikan dalam bentuk pembangunan sarana sanitasi oleh mitra Komida. Pinjaman harta diberikan dalam bentuk penyediaan barang yang dibutuhkan anggota (seperti televisi, kulkas, dll). Sedangkan pinjaman umum dan mikro bisnis diberikan dalam bentuk dana tunai. Seluruh pembiayaan tersebut diberikan kepada kelompok dengan sistem tanggung renteng.

Dalam upaya pemenuhan pembiayaan anggotanya, Komida memperoleh pendanaan dari berbagai pihak baik di dalam maupun luar negeri, diantaranya Grameen Foundation, Grameen Credit Agricole, dan beberapa lembaga serta perbankan lainnya. Pendanaan tersebut berbentuk pinjaman yang nantinya harus dikembalikan oleh Komida. Salah satu pendanaan yang berasal dari dalam negeri yaitu berasal dari Tekfin Mekar yang merupakan salah satu anak perusahaan dari Sampoerna Group. Sebelum memperoleh pendanaan dari Tekfin Mekar, Komida sudah memperoleh pendanaan dari Bank Sampoerna. Namun karena batas plafon pembiayaan yang diberikan oleh bank Sampoerna sudah mencapai maksimal maka pendanaan berikutnya menggunakan sistem chanelling melalui Tekfin Mekar.

Mekar memiliki sistem pembiayaan peer to peer (P2P) di mana aplikasi Mekar berperan sebagai media bertemunya peminjam dengan pemberi dana. Tekfin bertindak sebagai operator platform yang melakukan pengelolaan dan memfasilitasi proses pembiayaan (Huang, 2018) Visi utama Mekar yaitu meningkatkan akses finansial bagi para pelaku UMKM Indonesia dengan cara bermitra dengan institusi finansial non-bank yang beroperasi di seluruh Indonesia (Mekar.id). Mekar memilih Komida sebagai salah satu lending partner-nya karena Komida menggunakan pola grameen bank dan melakukan sistem manajemen mikro.

Dalam upaya untuk mencapai visinya, Mekar bekerja sama dengan berbagai lembaga keuangan seperti koperasi simpan pinjam, Bank Perkreditan Rakyat, dan lembaga keuangan lainnya, salah satunya adalah Komida. Dana yang disalurkan Mekar berasal dari dana perusahaan dan investor melalui sistem P2P. Kemampuan pelaku UMKM yang terbatas mengenai teknologi ini akan dijembatani oleh lending partner Mekar.

Hal tersebut dilakukan pula oleh lembaga Tekfin di negara lain. Di Asia, perbankan dan lembaga Tekfin melakukan hubungan simbiosis, di mana keduanya akan memperoleh manfaat dari hubungan kerja sama tersebut. Tekfin melihat perbankan sebagai pintu gerbang di pasar, sedangkan perbankan dapat beralih ke Tekfin untuk tetap berada dalam inovasi keuangan yang berkembang pesat dan mengikuti perubahan peraturan yang ada, serta memperoleh akses data yang besar untuk meningkatkan hubungan dengan pelanggan (Alexander dkk., 2017).

Skema kemitraan Komida dan Mekar dapat dilihat pada Gambar 2. Pertama, investor 
perorangan $\mathrm{P} 2 \mathrm{P}$ terlebih dahulu mengisi data yang diminta oleh Mekar melalui aplikasinya. Selanjutnya investor dapat melihat profil peminjam, jangka waktu pengembalian, dan besaran pengembalian atas investasi yang diberikan. Kemudian Mekar akan memberikan dana pinjaman kepada Komida sesuai dengan jumlah pinjaman yang diajukan oleh pihak Komida. Komida memfasilitasi anggotanya untuk dapat memperoleh pinjaman dengan cara mengumpulkan data anggota sesuai dengan persyaratan yang diminta oleh Mekar. Selanjutnya pegawai Komida memasukkan data tersebut ke dalam aplikasi Mekar sesuai dengan jumlah pinjaman yang diperoleh Komida.

Setelah pihak Komida memasukkan data anggotanya ke dalam aplikasi Mekar, sistem Mekar akan melakukan penilaian atas kelayakan calon peminjam untuk memperoleh pinjaman. Data peminjam pada Mekar merupakan data individu anggota kelompok Komida. Profil calon peminjam yang dianggap layak untuk memperoleh pinjaman akan langsung tercantum di dalam aplikasi dan investor dapat memilih calon peminjam yang akan dibiayai. Apabila terdapat calon peminjam yang belum terbiayai oleh investor maka akan dibiayai dengan dana perusahaan sehingga calon peminjam tetap dapat memperoleh pinjaman dengan cepat.

Peminjam yang merupakan anggota Komida melakukan pembayaran angsuran melalui Komida setiap minggunya. Apabila terdapat anggota kelompok yang pembayarannya tidak tepat waktu maka dilakukan tanggung renteng oleh anggota kelompok yang lain. Pembayaran tersebut dibayarkan Komida ke Mekar setiap bulan selama jangka waktu yang telah ditentukan. Selanjutnya Mekar mengembalikan dana investor beserta imbal hasil setiap bulannya hingga selesai jangka waktu pembayaran pinjaman oleh peminjam. Margin yang diperoleh oleh investor rata-rata sebesar $10 \%$ dari dana yang diinvestasikan.

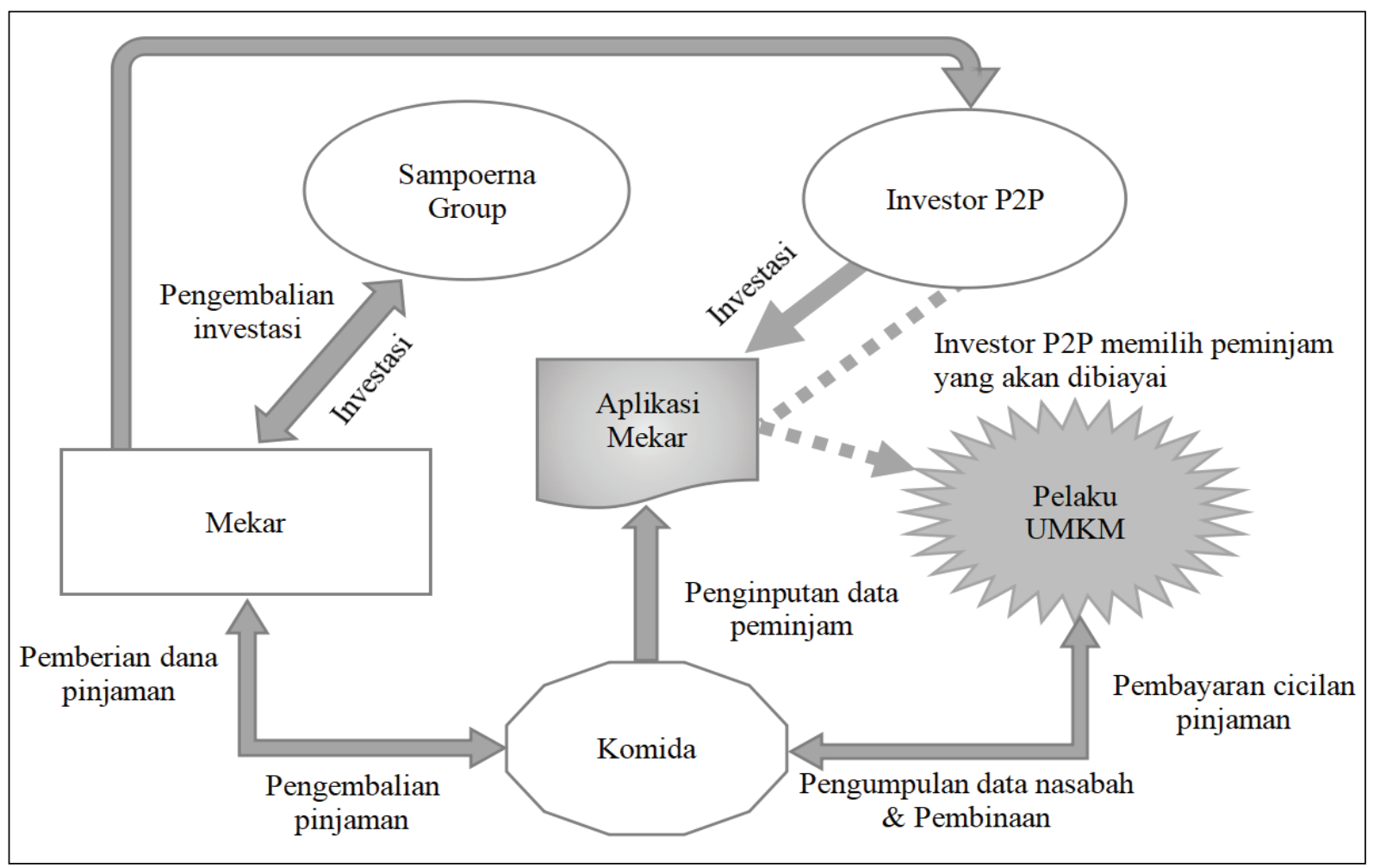

Sumber : P2E - LIPI, 2018

Gambar 2. Skema Kerjasama Mekar dengan Komida 
Dengan demikian manfaat yang diperoleh oleh Mekar yaitu memperoleh peminjam dari anggota Komida. Sebagai operator platform, Mekar juga memperoleh margin atas proses pembiayaan yang dilakukan melalui platform Mekar. Margin yang diperoleh Mekar hanya berkisar $2 \%$ per pinjaman. Sedangkan margin untuk Komida yaitu sebesar $8-13 \%$ dari bunga yang dibebankan kepada peminjam sebesar 20-25\%. Persentase margin yang diperoleh Komida tersebut menjadi keuntungan koperasi yang kemudian akan dibagikan sebagai Sisa Hasil Usaha (SHU) kepada seluruh anggota Komida setiap tahunnya.

Berikut ini akan diuraikan manfaat yang dirasakan oleh UMKM penerima pinjaman berdasarkan data hasil penyebaran kuesioner. Responden kuesioner Tekfin pembiayaan ini sebagian besar adalah wanita yaitu mencapai $96 \%$. Hal ini terjadi karena mayoritas anggota Komida adalah wanita. Dari 25 responden, $48 \%$ di antaranya berusia 30-40 tahun, 32\% berusia 40-50 tahun, dan sisanya berusia di atas 50 tahun. Responden yang berstatus menikah berjumlah $48 \%$, dan yang berstatus belum menikah berjumlah $28 \%$, sisanya berstatus janda. Sekitar setengah dari jumlah responden tidak bersekolah yaitu mencapai $46 \%$, sedangkan $29 \%$ di antaranya adalah lulusan SD, dan $21 \%$ sisanya adalah lulusan SMP. Sebagian besar responden jenis usahanya bergerak di bidang perdagangan, dan sekitar $32 \%$ bergerak di bidang produksi kerajinan. Dari karakteristik responden tersebut diketahui bahwa anggota Komida yang merupakan responden dan juga kreditur dari Tekfin Mekar sebagian besar berada pada usia produktif, namun berpendidikan rendah. Dilihat dari status perkawinannya, terlihat bahwa responden yang merupakan ibu rumah tangga namun juga memiliki usaha.

Anggota Komida yang merupakan kreditur Mekar menerima manfaat dari kredit yang diberikan tersebut. Berdasarkan hasil kuesioner, sebanyak $88 \%$ responden yang merasakan dampak positif atas kredit yang diberikan Mekar melalui Komida. Dampak terbesar yang dirasakan adalah kenaikan omset penjualan dengan ratarata peningkatan sebesar $61 \%$ per bulannya. Peningkatan omset tersebut berdampak pula pada peningkatan keuntungan dengan rata-rata peningkatan keuntungan responden sebesar 99\% setiap bulannya. Dampak lain yang juga dirasakan oleh responden yaitu meningkatnya jumlah pelanggan dan relasi usaha yang kini mereka miliki.

Dari hasil FGD dengan Tekfin Mekar di Jakarta pada Februari 2018 dan wawancara dengan Komida di Praya, NTB pada Maret 2018, diketahui bahwa kendala utama yang dihadapi baik oleh Komida maupun Tekfin Mekar yaitu kurangnya kelengkapan berkas seperti KTP yang seringkali tidak dimiliki oleh anggota Komida. Padahal KTP merupakan salah satu persyaratan dokumen yang wajib dimiliki oleh calon kreditur Tekfin Mekar. Dalam menghadapi kendala ini, karyawan Komida memberikan arahan dan pendampingan kepada anggotanya untuk membuat KTP dan kelengkapan dokumen lainnya.

Selain dampak positif yang diperoleh dari kerja sama yang dilakukan oleh Mekar dan Komida ini, terdapat beberapa kendala yang dihadapi dan masukan yang perlu diperhatikan. Pertama, suku bunga pinjaman yang diberikan kepada peminjam tergolong tinggi bila dibandingkan dengan suku bunga KUR yaitu sekitar 25\% per tahun sedangkan KUR hanya 7\% per tahun. Mekar dapat bekerja sama dengan Pemerintah dan lembaga perbankan penyalur KUR agar dapat membantu Pemerintah dan perbankan dalam menyalurkan pembiayaan kepada UMKM dengan tingkat suku bunga yang bersaing dengan KUR. Walaupun demikian, jangka waktu pinjaman dapat lebih ringan dan fleksibel yaitu mulai 6 bulan. Kedua, sistem Tekfin P2P yang dimiliki oleh Mekar seolah tidak berjalan pada sisi peminjam karena peran Komida yang begitu dominan mulai dari pengumpulan hingga penginputan data. Hal ini berkaitan dengan tingkat pendidikan anggota Komida yang rendah. Komida sebaiknya tidak hanya berperan sebagai fasilitator, akan tetapi juga dapat memberikan edukasi dalam menggunakan telepon seluler dan menggunakan aplikasi Tekfin.

\section{Sinergi Mandiri e-cash dan Koptan Wira Singe}

Selain Komida, terdapat koperasi lainnya di NTB yang juga bekerja sama dengan Tekfin yaitu Koperasi Tani (Koptan) Wira Singe. Koptan Wira 
Singe bekerja sama dengan Bank Mandiri tidak hanya dalam hal pembiayaan tetapi juga dalam bertransaksi keuangan melalui Mandiri e-cash. Mandiri e-cash merupakan Tekfin uang digital yang mempermudah transaksi keuangan hanya dengan menggunakan telepon seluler. Berbagai transaksi keuangan seperti penyetoran, penarikan tunai, transfer, pengecekan saldo, pembayaran, pembelian, dan sebagainya tanpa harus membuka rekening di kantor cabang Bank Mandiri.

Bank Mandiri yang sebelumnya telah bekerja sama dengan Koptan Wira Singe dalam hal pemberian kredit kepada anggota Koptan Wira Singe menawarkan produk barunya yaitu Mandiri e-cash yang serupa dengan rekening telepon seluler. Mandiri e-cash ini hanya dapat dimiliki oleh pengguna telepon seluler. Anggota Koptan Wira Singe menjadi salah satu target dari Bank Mandiri karena mayoritas anggotanya belum memiliki rekening tabungan. Oleh karena itu, Bank Mandiri melalui pengurus Koptan Wira Singe mengedukasi anggota koperasi untuk dapat mengakses perbankan dengan memanfaatkan layanan Mandiri e-cash.

Skema kerja sama Bank Mandiri dengan Koptan Wira Singe dapat dilihat pada Gambar 3. Pada alur nomor 1, para anggota Koptan Wira Singe diedukasi dan ditawarkan produk layanan Mandiri e-cash oleh pengurus Koptan Wira Singe. Para anggota Koperasi dibantu pengurus Koperasi untuk melakukan pendaftaran Mandiri $e$-cash. Layanan mandiri e-cash ini tidak hanya dapat diakses melalui aplikasi oleh pengguna telepon pintar tetapi dapat juga diakses melalui Unstructured Supplementary Service Data (USSD) *141*6\# pada telepon seluler biasa.

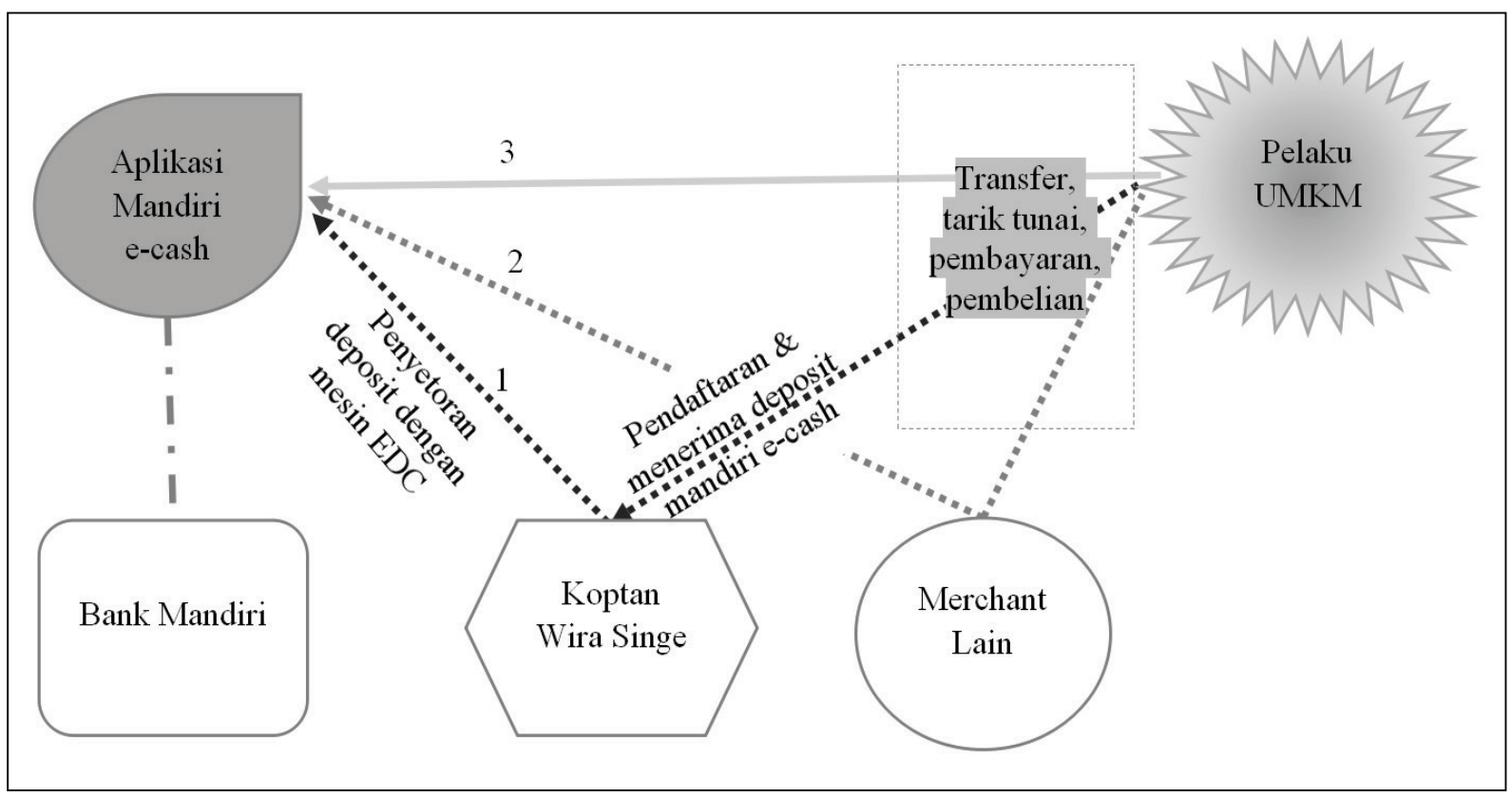

Sumber : P2E - LIPI, 2018

Gambar 3. Skema Kerjasama Mandiri e-cash dan Koptan Wira Singe

Pengurus Koperasi juga melakukan edukasi kepada para anggota koperasi untuk menabungkan uang atau menyetorkan deposit secara berkala yang dapat dilakukan melalui pengurus Koperasi. Pengurus koperasi menggunakan mesin Electronic Data Capture (EDC) sehingga transaksi yang dilakukan dapat langsung tercatat pada saat yang sama. Selanjutnya, pengurus koperasi yang akan menyetorkan dana anggota tersebut ke Bank Mandiri. Pada setiap transaksi deposit atau menabung tersebut, dana yang disetorkan oleh anggota akan terkena potongan sebesar Rp 3.000,sebagai biaya jasa koperasi. Meskipun Mandiri $e$-cash ini dapat menjadi pengganti tabungan, namun Mandiri e-cash memiliki batasan jumlah simpanan yaitu hanya sampai Rp 2 juta. Bagi pengguna yang akan melakukan simpanan lebih dari Rp 2 juta maka akan diarahkan untuk membuka rekening tabungan Bank Mandiri di kantor cabang Bank Mandiri. 
Mandiri e-cash juga memfasilitasi transaksi anggota Koperasi dalam melakukan pembelian sarana dan produk pertanian (Saprotan) yang disediakan oleh Koperasi. Pembayaran atas pembelian saprotan dapat langsung dipotong dari saldo mandiri e-cash yang dimiliki anggota. Anggota Koperasi juga dapat melakukan transaksi keuangan lainnya seperti transfer uang, penarikan tunai, pembelian pulsa dan token listrik, serta pembayaran lain-lain baik melalui Koperasi. Selain melalui Koperasi, berbagai transaksi tersebut juga dapat dilakukan melalui merchant Mandiri $e$-cash lainnya dengan alur proses seperti nomor 2, maupun langsung melalui aplikasi atau USSD telepon seluler anggota seperti alur proses nomor 3. Atas setiap transaksi keuangan yang dilakukan melalui Koperasi, maka Koperasi akan memperoleh imbal jasa sebesar Rp 1.000,-. Imbal jasa yang diperoleh Koperasi tersebut akan dihitung sebagai keuntungan koperasi.

Untuk mengetahui penggunaan layanan Mandiri e-cash oleh anggota koperasi akan dianalisis hasil penyebaran kuesioner. Namun sebelum itu terlebih dahulu dikemukakan karakteristik responden. Anggota Koperasi yang menjadi responden sebesar $60 \%$ berjenis kelamin perempuan. Sekitar $48 \%$ dari total responden berusia di bawah 30 tahun, $28 \%$ berusia $30-40$ tahun, $19 \%$ berusia di atas 50 tahun, dan sisanya berusia 40-50 tahun. Mayoritas responden berstatus menikah yaitu mencapai $72 \%$. Dari sisi pendidikan, latar belakang pendidikan responden Tekfin pembayaran ini lebih tinggi dibandingkan responden Tekfin pembiayaan, yaitu sekitar $60 \%$ responden merupakan lulusan SMA. Walaupun Koperasi ini merupakan Koperasi Tani, namun ternyata banyak anggotanya yang pekerjaan utamanya bukanlah sebagai petani melainkan sebagai pedagang yaitu mencapai $75 \%$. Hanya $17 \%$ responden yang usaha pekerjaan utamanya sebagai petani dan peternak. Dari karakteristik tersebut diketahui bahwa secara umum responden Tekfin pembayaran maupun Tekfin Pembiayaan memiliki karakteristik yang serupa, perbedaan yang cukup terlihat jelas yaitu dari sisi tingkat pendidikan responden Tekfin pembayaran yang lebih tinggi sehingga dapat mempermudah proses edukasi yang diberikan.

Layanan Mandiri e-cash ini lebih banyak digunakan oleh anggota Koperasi dengan frekuensi harian dan mingguan. Berdasarkan hasil kuesioner, jenis transaksi yang paling sering digunakan oleh anggota Koperasi adalah pembayaran tagihan dan pembayaran transaksi jual-beli. Sedangkan transaksi yang paling jarang dilakukan adalah setor tunai. Hadirnya Mandiri $e$-cash di tengah masyarakat ini telah memberi kemudahan bagi masyarakat dalam bertransaksi keuangan tanpa perlu lagi datang langsung ke lembaga perbankan maupun toko untuk melakukan pembayaran tagihan dan jual-beli. Rendahnya frekuensi transaksi setor tunai yang dilakukan oleh anggota Koperasi diduga karena adanya potongan yang dibebankan oleh Koperasi dalam setiap transaksi setor tunai, di mana sebagian besar anggota Koperasi mengaku biaya potongan tersebut cukup tinggi dan memberatkan anggota.

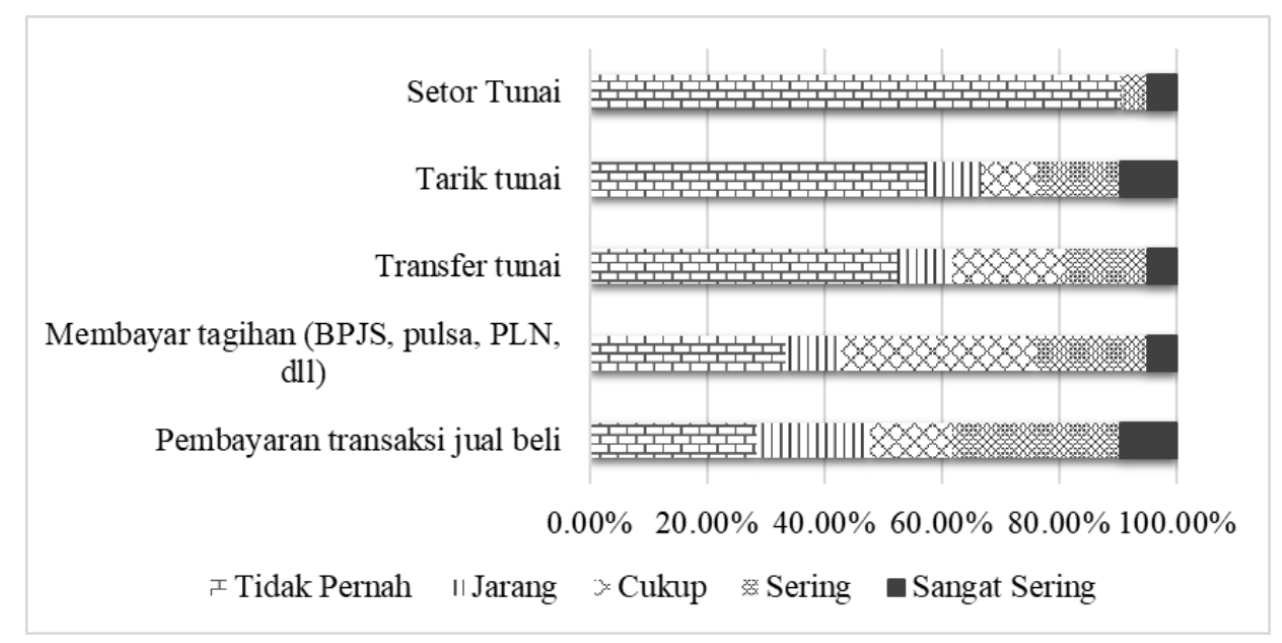

Sumber : P2E - LIPI, 2018

Gambar 4 . Transaksi Keuangan melalui Tekfin Pembayaran 
Walaupun demikian, respon anggota Koptan Wira Singe terhadap penggunaan Mandiri e-cash ini cukup baik, terlihat dari jumlah anggota yang telah teregistrasi Mandiri e-cash cukup banyak. Dalam kurun waktu 3 bulan terhitung sejak Januari hingga Maret 2018 terdapat 300 anggota Koptan Wira Singe yang telah terdaftar dan memiliki akun Mandiri e-cash. Jumlah tersebut tentunya masih akan terus bertambah karena pendekatan yang dilakukan pengurus untuk mengedukasi dan mensosialisasikan manfaat dan cara penggunaan Mandiri $e$-cash terus dilakukan. Sebagian besar para anggota Koptan Wira Singe mengakui tertarik untuk menggunakan Mandiri $e$-cash yaitu karena menginginkan uang mereka lebih aman, dan ingin mencoba hal baru.

Kerja sama yang dijalin oleh Koptan Wira Singe dan Bank Mandiri ini, baik langsung maupun tidak langsung telah memberikan manfaat terhadap beberapa pihak yang terlibat di dalamnya. Tidak hanya Koptan Wira Singe dan Bank Mandiri saja, tetapi juga anggota Koptan Wira Singe sebagai nasabah Mandiri e-cash. Koptan Wira Singe memperoleh keuntungan dari imbal jasa yang dibebankan kepada anggota atas setiap transaksinya. Imbal jasa tersebut selanjutnya akan dibagikan kepada anggota sebagai SHU setiap tahunnya. Manfaat yang diperoleh oleh Bank Mandiri selaku lembaga penyelenggara Tekfin pembayaran yaitu telah terbantu dalam melakukan sosialisasi dan pendekatan kepada masyarakat untuk mengedukasi dan memperoleh nasabah baru. Sedangkan anggota Koptan Wira Singe sendiri tidak hanya memperoleh edukasi menabung dan kemudahan dalam melakukan transaksi keuangan, akan tetapi transaksi penjualan dan keuntungan usaha mereka meningkat. Berdasarkan hasil kuesioner, diketahui bahwa transaksi penjualan setelah menggunakan Mandiri e-cash meningkat dengan rata-rata peningkatan $20 \%$. Hal tersebut berdampak pula pada peningkatan keuntungan yang diperoleh dengan rata-rata peningkatan sebesar 33\% setiap bulannya.

Sisi lain dari dampak positif yang diperoleh dari sinergi yang dilakukan Bank Mandiri dan Koptan Wira Singe ini, terdapat pula sisi lain yang perlu diperhatikan. Biaya administrasi yang dibebankan oleh pihak Koperasi yang cukup memberatkan pengguna perlu diperhitungkan kembali besarannya agar frekuensi menabung anggota menjadi lebih sering. Misalnya, biaya administrasi diturunkan dari semula Rp 3.000,per transaksi menjadi Rp 1.000,- untuk setiap transaksi menabung di bawah Rp 100.000,- dan Rp 2.000 ,- untuk setiap transaksi di atas Rp 100.000,-. Selain itu, Koperasi juga dapat memanfaatkan Mandiri e-cash untuk memfasilitasi pembayaran simpanan wajib anggota Koperasi, sehingga, jumlah anggota Koperasi yang menggunakan Mandiri e-cash akan turut meningkat.

\section{KESIMPULAN DAN SARAN}

Tekfin Mekar sebagai operator platform yang melakukan pengelolaan dan memfasilitasi proses pembiayaan dengan sistem P2P. Tekfin Mekar bekerja sama dengan Komida sebagai pemberi dana pinjaman untuk anggota Komida. Sementara itu, Komida berperan sebagai fasilitator bagi anggota untuk memperoleh pinjaman dalam mengumpulkan dan menginput data anggota Komida ke dalam sistem Mekar. Mekar sendiri memperoleh pendanaannya berasal dari dana perusahaan dan investor.

Dari sistem kerja sama ini, seluruh pihak dalam sistem ini baik Mekar, Komida, investor maupun anggota Komida memperoleh dampak positif. Mekar, Komida, dan investor memperoleh imbal hasil dari bunga pinjaman peminjam, sedangkan anggota Komida memperoleh bantuan dari pinjaman yang diberikan Mekar melalui Komida. Selain itu, manfaat lain yang diperoleh anggota Komida yaitu adanya peningkatan transaksi penjualan dan keuntungan dari pinjaman yang digunakan untuk mengembangkan usahanya, serta bertambahnya relasi usaha. Hal yang perlu diperhatikan oleh Mekar yaitu besaran bunga yang saat ini relatif lebih tinggi dibandingkan bunga KUR. Ke depan, Mekar dapat bekerja sama dengan Pemerintah dan perbankan penyalur KUR dalam menyalurkan KUR sehingga besaran bunganya dapat bersaing. Sedangkan Komida perlu lebih memberikan edukasi kepada anggotanya untuk menggunakan telepon seluler dan mengaplikasikan Tekfin agar ke depan dapat lebih mandiri.

Selanjutnya, Tekfin Mandiri e-cash merupakan salah satu layanan Bank Mandiri 
yang berbasis telepon seluler. Bank Mandiri bekerja sama dengan Koptan Wira Singe untuk membantunya dalam mengedukasi anggota Koperasi agar dapat mengakses layanan keuangan, salah satunya Mandiri e-cash ini. Jenis transaksi yang dapat dilakukan melalui Mandiri e-cash ini di antaranya menabung, tarik tunai, transfer, pembayaran, dan pembelian. Mandiri e-cash ini dapat diakses dengan menggunakan aplikasi maupun menu USSD pada telepon seluler. Selain itu, Koptan Wira Singe membantu anggotanya dengan memberikan edukasi dan memfasilitasi transaksi keuangan yang ingin dilakukan anggota Koperasi.

Bank Mandiri, Koptan Wira Singe, dan anggota Koperasi memperoleh manfaat dari sistem kerja sama ini. Bank Mandiri terbantu untuk mengedukasi masyarakat dan memperoleh nasabah baru. Sedangkan Koptan Wira Singe memperoleh imbal hasil dari biaya administrasi yang dibebankan kepada anggotanya dalam setiap transaksi yang dilakukan. Anggota Koperasi memperoleh kemudahan dalam bertransaksi keuangan, keamanan dana, dan peningkatan transaksi serta keuntungan usaha. Walaupun demikian, para anggota mengaku bahwa biaya administrasi yang dibebankan pada setiap transaksi menabung cukup memberatkan. Untuk itu, Koptan Wira Singe perlu meninjau ulang besaran biaya administrasi tersebut agar tidak memberatkan anggota dan transaksi menabung dapat meningkat. Koptan Wira Singe juga dapat memanfaatkan layanan Mandiri e-cash ini sebagai media untuk pembayaran simpanan wajib anggota setiap bulannya.

Sinergi antara lembaga Tekfin dengan lembaga keuangan baik perbankan dan non bank ini dapat diterapkan dan dikembangkan di daerah lain. Seperti yang dikemukakan Alexander dkk., (2017), dengan adanya sinergi ini, maka kedua belah pihak akan memperoleh manfaat dari kerja sama yang dilakukan. Begitu pula dengan masyarakat khususnya nasabah juga akan memperoleh manfaat tersebut. Namun tentunya perlu didukung dengan adanya peraturan yang kondusif agar aktivitas ini dapat berjalan dengan aman dan lancar.

\section{UCAPAN TERIMA KASIH}

Ucapan terima kasih saya berikan kepada Yeni Saptia selaku koordinator tim beserta seluruh anggota tim DIPA Keuangan Inklusif Pusat Penelitian Ekonomi LIPI tahun 2018 yaitu Agus Eko Nugroho, Darwin, M. Soekarni, Jiwa Sarana, Tuti Ermawati, Ernany Dwi Astuty, Zarida, Nika Pranata yang telah memberikan bimbingan serta memberikan izin untuk penggunaan data penelitian bagi kepentingan penulisan artikel ini. Ucapan terima kasih juga saya sampaikan kepada PT Mekar Investama Sampoerna, Komida, Koptan Wira Singe, serta masyarakat NTB yang telah membantu dalam memberikan data dan informasi untuk penelitian ini.

\section{DAFTAR PUSTAKA}

Dinas Koperasi dan UMKM Provinsi N T B. (2018). Paparan FGD Arah Kebijakan Pengembangan KUMKM di Provinsi NTB.

Alexander, A. J., Shi, L., \& Solomon, B. (2017). How Fintech is Reaching the Poor in Africa and Asia : A Start-Up Perspective. IMF Financial Access Survey, (March). Retrieved from https://www.ifc.org/wps/wcm/connect/ f745fd31-a9aa-4736-b0ba-4ac2956f96dc/ EmCompass + Note $+34+$ DFS + and + FinTec $\mathrm{h}+\mathrm{Mar}+28+$ FINAL.pdf?MOD=AJPERES

Chishti, S., \& Barberis, J. (2016). The Fintech book: the financial technology handbook for investors, entrepreneurs and visionaries. Journal of Indonesian Economy and Business, 31(3), 315. https://doi. org/10.1002/9781119218906

Huang, R. H. (2018). Online P2P Lending and Regulatory Responses in China: Opportunities and Challenges. European Business Organization Law Review, 19(1), 63-92. https://doi.org/10.1007/s40804-0180100-Z

KPMG, \& Nasscom. (2016). Fintech in India : A Global Growth Story. Retrieved from https://assets.kpmg.com/content/dam/kpmg/ pdf/2016/06/FinTech-new.pdf 
Kshetri, N. (2016). Big data's role in expanding access to financial services in China. International Journal of Information Management, 36(3), 297-308. https://doi. org/10.1016/j.ijinfomgt.2015.11.014

Lee, I. (2016). Fintech: Ecosystem and Business Models. Advanced Science and Technology Letters, 142(10), 57-62. https://doi. org/10.14257/astl.2016.142.10

Lee, I., \& Shin, Y. J. (2018). Fintech: Ecosystem, business models, investment decisions, and challenges. Business Horizons, 61(1), 35-46. https://doi.org/10.1016/j. bushor.2017.09.003

Morgan, P. J., \& Trinh, L. Q. (2019). FINTECH AND FINANCIAL LITERACY Asian Development Bank Institute. ADBI Working Paper Series.

Muchlis, R. (2018). Analisis SWOT Financial Technology (Fintech) Pembiayaan Perbankan Syariah Di Indonesia (Studi Kasus 4 Bank Syariah Di Kota Medan). AT-TAWASSUTH: Jurnal Ekonomi Syariah.

Muzdalifa, I., Rahma, I. A., \& Novalia, B. G. (2018). Peran Fintech Dalam Meningkatkan Inklusif Keuangan Pada Umkm Di Indonesia. Masharif Al-Syariah: Jurnal Ekonomi Dan Perbankan Syariah.

Ndung'u, N. (2018). The M-Pesa Technological Revolution for Financial Services in Kenya: A Platform for Financial Inclusion. In Handbook of Blockchain, Digital Finance, and Inclusion, Volume 1 (1st ed., Vol. 1, pp. 37-56). Elsevier Inc. https://doi. org/10.1016/B978-0-12-810441-5.00003-8
OECD. (2018). Financial Markets, Insurance and Private Pensions: Digitalisation and Finance.

Rahman, A. (2009). Financial Inclusion as a Tool for Combating Poverty: The Bangladesh Approach. In 1st AFI Global Policy Forum (pp. 1-14). Nairobi.

Ranganathan, K., \& Kapoor, A. (2014). Eko: The Mobile Phone as a Financial Identity. Asian Case Research Journal. https://doi. org/10.1142/s0218927514500060

Rizal, M., Maulina, E., \& Kostini, N. (2019). FINTECH SEBAGAI SALAH SATU SOLUSI PEMBIAYAAN BAGI UMKM. AdBispreneur. https://doi.org/10.24198/ adbispreneur.v3i2.17836

Romanova, I., \& Kudinska, M. (2016). Banking and fintech: A challenge or opportunity? Contemporary Studies in Economic and Financial Analysis, 98, 21-35. https://doi. org/10.1108/S1569-375920160000098002

Shim, Y., \& Shin, D. H. (2016). Analyzing China's Fintech Industry from the Perspective of Actor-Network Theory. Telecommunications Policy, 40(2-3), 168-181. https://doi. org/10.1016/j.telpol.2015.11.005

Wonglimpiyarat, J. (2017). FinTech banking industry: a systemic approach. Foresight, 19(6), 590-603. https://doi.org/10.1108/ FS-07-2017-0026 
